\title{
Potential immunotherapeutic role of interleukin-2 and interleukin- 12 combination in patients with hepatocellular carcinoma
}

This article was published in the following Dove Press journal:

Journal of Hepatocellular Carcinoma

9 June 2014

Number of times this article has been viewed

\author{
Abdulwahab Ali Gabeen' \\ Fatma Farag Abdel-Hamid' \\ Motawa Eisa El-Houseini ${ }^{2}$ \\ Shadia Abdel-Hamid Fathy' \\ 'Biochemistry Department, Faculty \\ of Science, Ain Shams University, \\ Cairo, Egypt; ${ }^{2}$ Cancer Biology \\ Department, National Cancer \\ Institute $(\mathrm{NCl})$, Cairo University, \\ Cairo, Egypt
}

Background: Many recent therapeutic interventions are necessary to improve the treatment of hepatocellular carcinoma (HCC), including immunotherapy, which seems to offer one of the new realistic therapeutic modalities. This study aims to investigate the optimization of immunotherapy for HCC patients by appraisal of both interferon (IFN)- $\gamma$ levels and phenotyping of lymphocytes obtained from peripheral blood and fine-needle aspirates.

Methods: The isolated lymphocytes were cultured in the presence of interleukins (IL)-2, IL-4, and IL-12. Enzyme-linked immunosorbent assay and flow cytometric techniques were used for the assessment of human IFN- $\gamma$ production and the studied T-cell subpopulations, respectively.

Results: Mixed cell populations of peripheral blood lymphocytes and tumor infiltrating lymphocytes treated with IL-2 plus IL-12 showed a marked and significant elevation in IFN- $\gamma$ levels in their culture media, a significant decrease in the percentage of cluster of differentiation $(\mathrm{CD}) 4^{+} \mathrm{CD} 25^{+}$regulatory T-cells, and a nonsignificant increase in the percentage of $\mathrm{CD} 8^{+}$ cytotoxic T-cells. Meanwhile, IL-2 plus IL-4 treatment demonstrated nonsignificant effects.

Conclusion: Our data suggested that IL-12 together with IL-2 caused a suppression of $\mathrm{CD} 4{ }^{+} \mathrm{CD} 25^{+}$regulatory T-cells and an elevation of IFN- $\gamma$ levels, which play a crucial immunotherapeutic role in the management of HCC patients.

Keywords: HCC, immunotherapy, fine-needle aspirates, tumor infiltrating lymphocytes, interferon-gamma, interleukins

\section{Introduction}

Hepatocellular carcinoma (HCC) is the most common primary liver tumor and it represents the third-leading cause of cancer-related deaths in the world. ${ }^{1}$

Lymphocytes contribute to the tumor microenvironment through immunity and inflammation. In HCC, extremely marked infiltration of T-cells, including predominant cluster of differentiation (CD) $8^{+}$T-cells has been shown to be closely associated with a low recurrence rate and good prognosis. $\mathrm{CD}^{+}$cytotoxic T-lymphocytes (CTLs) can directly kill target cells by releasing granules, including membrane-lytic materials such as perforin and granzymes, thereby playing a central role in antitumor immunity. ${ }^{2}$

T-regulatory cells, another subset of T-cells, are a minor but functionally unique population of T-cells that maintain immune homeostasis in immune tolerance, and they also play a role in controlling autoimmunity. They are thought to have a positive effect on tumor growth through the suppression of antitumor immune cells. ${ }^{3}$

Interleukin (IL)-2 is a pleiotropic cytokine that drives T-cell growth, induces the differentiation of regulatory T-cells (T-regs), and mediates activation-induced
Correspondence: Abdulwahab Ali Gabeen Department of Biochemistry, Faculty of Science, Ain Shams University, 7 Basus, Al-Qanater Al-Khayriya St, Qalyubia Governorate, I375I, Egypt

Tel +20 I22 5150309

Email abdulwahabgabeen@yahoo.com 
cell death. ${ }^{4}$ It is an important cytokine in the generation of antitumor immunity mediated by CTLs. ${ }^{5}$

IL-4 is a multifunctional pleiotropic cytokine produced mainly by activated $\mathrm{T}$ cells but also by mast cells, basophils, and eosinophils. ${ }^{6}$ It is known for defining the so-called $\mathrm{Th}_{2}$ phenotype of lymphocytes and for regulating cell proliferation and apoptosis. ${ }^{6}$

IL-12, known as T-cell differentiation factor, is an important immune regulatory cytokine produced mainly by antigen-presenting cells. ${ }^{7}$ Its main physiological functions include that it can induce hematopoietic cell proliferation, enhance cytotoxicity, facilitate the expression of cytotoxic mediators, produce type-1 cytokines (particularly interferon [IFN]- $\gamma$ ), and favor cell differentiation. ${ }^{7}$

IFN- $\gamma$ is a pleiotropic cytokine with immunomodulatory, antiviral, and antiproliferative effects. ${ }^{8}$ This cytokine is produced predominantly by natural killer and natural killer T-cells as part of the innate immune response, and by Th, CD4 and CD8 CTL effector T-cells once antigen-specific immunity develops. ${ }^{9}$ IFN- $\gamma$ produced by tumor infiltrating T-cells might play two distinct roles in antitumor activity: the activation of antitumor T-cells; and direct tumoricidal activity. ${ }^{10}$

\section{Subjects and methods}

\section{Sample selection}

Thirty-eight patients with $\mathrm{HCC}$ in the age range of 39-72 years were enrolled in this study. They were selected from the outpatient clinic of the Clinical Pathology Department of the National Cancer Institute (NCI), Cairo University (Cairo, Egypt). After obtaining the appropriate written informed consent from patients following the institutional review board's approved protocols, blood and liver aspirate specimens were collected from patients with HCC. Sterilized samples of fine-needle aspiration (FNA) and heparinized peripheral blood (HPB) were obtained by NCI radiologists. HPB samples drawn from ten apparently healthy persons were considered as normal healthy controls. All samples were subjected to the following criteria: routine clinical examination; pathological examination; cell count with viability; and biochemical parameters represented by IFN- $\gamma$ measurements and phenotypic analyses of the cultured cells being studied.

\section{Cell density and viability studies}

Mononuclear leukocytes were extracted from liver FNA and peripheral blood samples, as previously described; ${ }^{11,12}$ they were isolated using Ficoll-Hypaque separation media. ${ }^{13}$ The lymphocytes were purified from the mono- cytes by allowing the latter to adhere to plastic flasks for 1 hour, after which the nonadherent lymphocytes were pipetted from the flasks. ${ }^{14} \mathrm{~A}$ total of $20 \mu \mathrm{L}$ of lymphocytes were presented for the count and viability studies using a hemocytometer, phosphate-buffered saline, and $0.4 \%$ trypan blue.

\section{Cell culture and interleukin treatment}

Lymphocytes were cultivated in cell culture medium (Sigma-Aldrich Co., St Louis, MO, USA [RPMI]-1640) supplemented with $10 \%$ heat-inactivated fetal calf serum (FCS), $100 \mathrm{U} / \mathrm{mL}$ of penicillin, $100 \mu \mathrm{g} / \mathrm{mL}$ of streptomycin, and one or a combination of the following three cytokines: recombinant human IL-2 (IL-2; $4 \mathrm{ng} / \mathrm{mL}$ ); recombinant human IL-12 (IL-12; $4 \mathrm{ng} / \mathrm{mL}$ ); and recombinant human IL-4 (IL-4; $40 \mathrm{ng} / \mathrm{mL}$ ). These concentrations were the optimized values taken from dose-response curves (Figure 1). Peripheral blood lymphocytes (PBLs) were cultivated at $2 \times 10^{5}$ cells $/ \mathrm{mL}$, where mixed lymphocytes (tumor infiltrating lymphocytes [TILs] + PBLs) were cultivated together at a ratio of $1: 1$ at $1 \times 10^{5}$ cells $/ \mathrm{mL}$ for each. Incubation was carried out at $37^{\circ} \mathrm{C}$ with $5 \% \mathrm{CO}_{2}$.
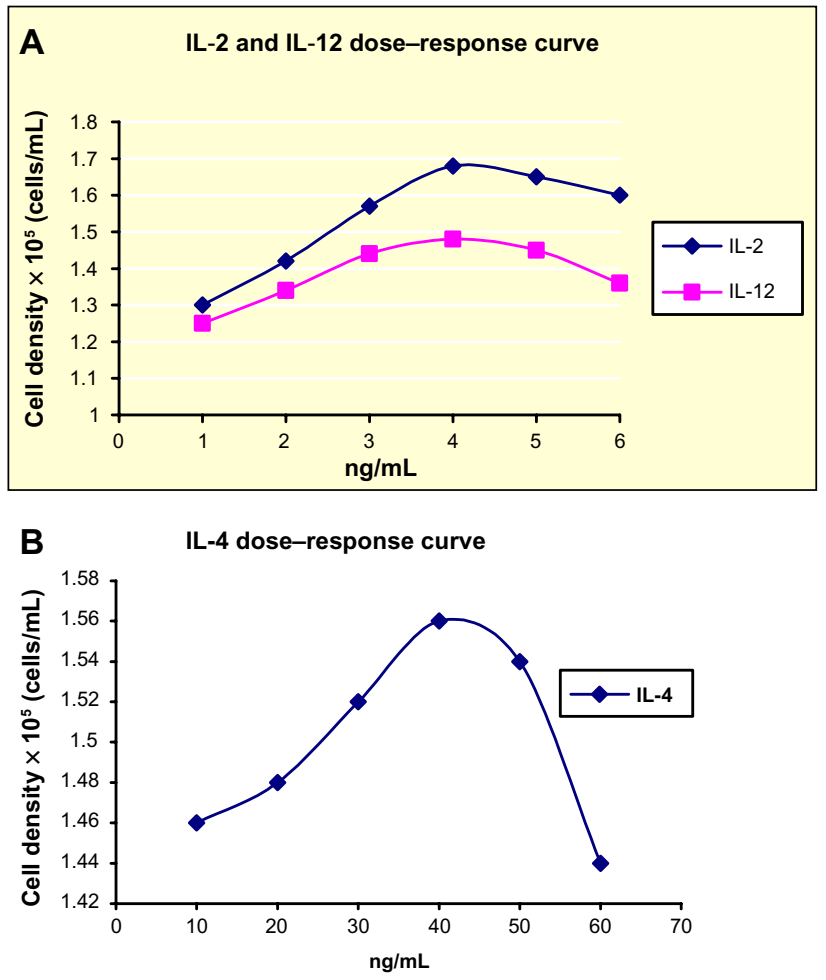

Figure I Dose-response curves for the lymphocyte cell densities of a healthy subject after treatment with different concentrations of IL-2, IL-4, and IL-I 2 .

Notes: (A) Dose concentration with $4 \mathrm{ng} / \mathrm{mL}$ of IL-2 and IL- 12 yield the maximal lymphocyte cell densities; (B) dose concentration with $40 \mathrm{ng} / \mathrm{mL}$ of IL-4 yield the maximal lymphocyte cell densities.

Abbreviation: IL, interleukin. 
HCC patients were mainly categorized into two groups: group 1 included a set of patients in which isolated lymphocyte samples from the FNA and HPB were obtained from the same patient. The group was further divided into two classes: the first was concerned with a study of the lymphocytic mixture (TILs and PBLs) collected from both samples (group 1; class A); the second was concerned with a study of PBLs alone (group 1; class B). In both classes, three aliquots were cultured and propagated ex vivo with IL-2 for 48 hours. Further, two of these aliquots were subjected to either the addition of IL-4 or IL-12 and they were recultured for 72 hours. Group 2 included another set of patients in which HPB samples were the only source of isolated lymphocytes. In this group, two aliquots were studied for 72 hours for a comparison of the two different and initial combined IL treatments (IL-2/IL-4 and IL-2/IL-12).

\section{Biochemical and immunological parameters \\ Detection of IFN- $\gamma$}

Cell-free supernatants were collected and assayed for the human IFN- $\gamma$ enzyme-linked immunosorbent assay (ELISA) ${ }^{15}$ according to the BMS228 ELISA manual (Bender MedSystems GmbH, Vienna, Austria). IFN-gamma standard was provided with the ELIZA kit in the form of a vial; its lyophilized content was dissolved by the addition of distilled water for the preparation of IFN-gamma standard concentration $(200 \mathrm{ng} / \mathrm{mL})$. External standard dilutions were prepared in seven tubes - one for each standard point. The 1:2 serial dilutions yielded standard concentrations ranging from 100.00 $\mathrm{pg} / \mathrm{mL}$ to $1.56 \mathrm{pg} / \mathrm{mL}$. Cell-free supernatants were diluted $1: 2$ (50 $\mu \mathrm{L}$ of the sample $+50 \mu \mathrm{L}$ of the sample diluent). Aliquots of diluted supernatants of the samples and standard concentrations were loaded onto the ELISA plate in duplicate at $100 \mu \mathrm{L}$ per well. The sample diluent served as a blank. A total of $50 \mu \mathrm{L}$ of biotin conjugate was added to each well, followed by 2 hours of incubation at room temperature. After washing the microwell strips with wash buffer, $100 \mu \mathrm{L}$ of diluted streptavidin-horseradish peroxidase was added, and this was followed by 1 hour of incubation at room temperature. After extensive washing, a color was developed by incubation with $100 \mu \mathrm{L}$ of the substrate solution. After adding $100 \mu \mathrm{L}$ of Stop Solution (Bender MedSystems $\mathrm{GmbH}$ ), the optical density at $450 \mathrm{~nm}$ was determined for each well by a microplate reader. The concentration of samples read from the standard curve was multiplied by the dilution factor $(\times 2)$. Sensitivity limits for the assay were $<2 \mathrm{pg} / \mathrm{mL}(\sim 0.99 \mathrm{pg} / \mathrm{mL})$.

\section{Flow cytometric analysis of lymphocytes}

Immunophenotyping (IPT) was carried out according to the protocol used in the Bone Marrow Unit, Clinical Pathology Department, National Cancer Institiute, Cairo University. The studied T-cell subpopulations were analyzed using Partec PAS-III flow cytometer (DakoCytomation, Münster, Germany). The studied cells were subjected to IPT analysis in terms of CD25-fluorescein isothiocyanate, CD8phycoerythrin (PE), and CD4-PE-Cya-5. ${ }^{16}$ An example of the flow cytometric analysis and gating of the lymphocytes is shown in Figure 2.

\section{Reagents and chemicals}

All tissue culture media contained RPMI-1640 medium (Sigma Aldrich, St Louis, MO, USA), 10\% heat-inactivated FCS (Biochrom AG, Berlin, Germany), and $100 \mathrm{U} / \mathrm{mL}$ of penicillin and $100 \mu \mathrm{g} / \mathrm{mL}$ of streptomycin (Biochrom). Separating of lymphocytes was conducted using FicollHypaque (Seromed, Biochrom KG, Berlin, Germany). IL-2 was purchased from Roche Diagnostics GmbH (Mannheim, Germany), IL-4 was purchased from R\&D Systems, Inc., (Minneapolis, MN, USA), and recombinant human Interleukin-12 (RH) IL-12 was purchased from Gibco ${ }^{\circledR}$ Invitrogen Corporartion (Camarillo, CA, USA). ELISA (Bender MedSystems $\mathrm{GmbH}$ ) was used for the IFN- $\gamma$ assays. Monoclonal antibodies anti-CD3, anti-CD4 and anti-CD8 obtained from DakoCytomation (Ely, Cambridgeshire, UK); anti-CD25 purchased from Fitzgerald Industries International (Acton, MA, USA) were used for the flow cytometric analysis.

\section{Statistical analysis}

Analysis of the data was carried out with the aid of SPSS package version 20 (IBM Corporation, Armonk, NY, USA). One-way analysis of variance was carried out to compare the means of patients and the control group under a normal distribution. The paired samples $t$-test was used to measure the effect of treatment on the samples within the same group or class. A $P$-value $\leq 0.05$ was considered significant.

\section{Results \\ Cell count and viability studies}

For the PBLs, the cell viability was $95 \%-98 \%$ and the cell count was 1.15 million-1.75 million cell $/ \mathrm{mL}$, whereas for TILs the viability was $90 \%-95 \%$ and the cell count was 0.23 million- 0.5 million cell/mL. TILs were assessed by a Partec PAS-III flow cytometer (DakoCytomation) using anti-CD3, anti-CD4, and anti-CD8 monoclonal antibodies, as reported previously. ${ }^{17}$ 

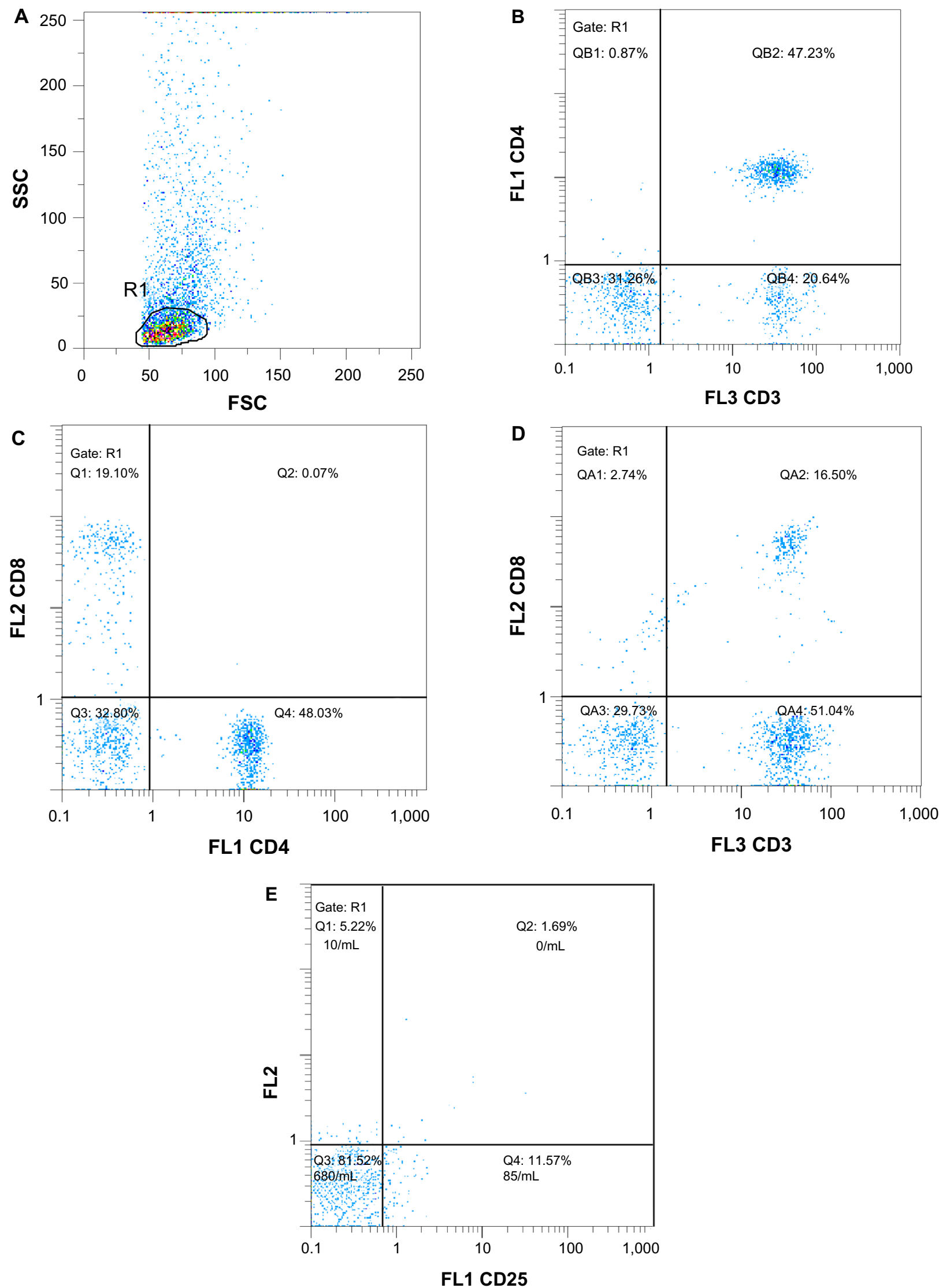

Figure 2 An example of flow cytometric analysis and gating on lymphocytes.

Notes: (A) Gating on viable cultured lymphocytes. (B) Analysis and statistics showing $\mathrm{CD}^{+} \mathrm{CD}^{+} \mathrm{T}$-cells. (C) Analysis and statistics differentiating CD4 $4^{+} \mathrm{T}$-cells and $\mathrm{CD} 8^{+}$ T-cells. (D) Analysis and statistics showing CD3 ${ }^{+} \mathrm{CD} 8^{+} \mathrm{T}$-cells. (E) Analysis and statistics of $\mathrm{CD} 3^{+} \mathrm{CD} 4^{+} \mathrm{T}$-cells showing the percentage of $\mathrm{CD} 25^{+} \mathrm{T}$-cells.

Abbreviations: SSC, side scatter; FSC, forward scatter; FL, fluorescence parameter; CD, cluster of differentiation. 


\section{IFN- $\gamma$ evaluation in culture supernatants}

In our experiment, the effect of the addition of either IL-12 or IL-4 to IL-2 on IFN- $\gamma$ secretion from lymphocytes was deliberated. For healthy control PBLs, the addition of IL-12 to IL-2 reflected the stimulatory effect which was represented by an elevation in IFN- $\gamma$ levels; $P<0.001$ (Table 1). Reviewing the effect of the studied ILs on the secretory outcome of the mixed lymphocytes of the HCC samples, IL-2 + IL-4 yielded IFN- $\gamma$ levels lower than that of IL- $2 ; P<0.05$; meanwhile, IL-2 + IL-12 showed the highest levels compared to either IL-2 + IL-4 or IL-2 alone; $P<0.001$ (Table 2; group 1, class A). Comparing the additive effect of IL-4 to IL-2, a nonsignificant increase of IFN- $\gamma$ levels was shown in cultured PBLs (Table 2; group 1, class B), which opposed the significant decrease shown in mixed lymphocytes; $P<0.05$ (Table 2; group 1, class A). Regarding the initial combined treatment of HCC PBLs, IL-2 + IL-12 showed a significant increase of IFN- $\gamma$ in relation to IL-2 + IL-4; $P<0.05$ (Table 3).

\section{Immunological characterization of the treated lymphocytes}

In our study, phenotyping of the PBLs of healthy controls reflected the effect of the studied ILs on the immunological cell pattern, where the addition of IL-12 to IL-2 improved the percentage of $\mathrm{CD} 4^{+} \mathrm{T}$-cells $(P<0.001)$, declined that of $\mathrm{CD} 4{ }^{+} \mathrm{CD} 25^{+}$T-regs; $P<0.05$, and it showed a nonsignificant elevation in $\mathrm{CD} 8^{+}$cytotoxic T-cells (Table 4). The same theme was similarly represented in HCC samples, but the significant decrease shown in $\mathrm{CD} 4^{+} \mathrm{CD} 25^{+}$T-regs either in the mixed lymphocytic population ( $P<0.05$, Table 5; group 1, class A) or among PBLs $(P<0.01$, Table 5; group 1, class B) was accompanied by nonsignificant elevations in the corresponding percentages of both $\mathrm{CD}^{+}$and $\mathrm{CD} 8^{+} \mathrm{T}$-cells (Table 5).

Regarding the additive effect of IL-4 in the cultured mixed lymphocytes, IL-4 in combination with IL-2 played a significant inhibitory role on $\mathrm{CD} 4^{+} \mathrm{T}$-cells $(P<0.01)$ and a significant stimulatory role on $\mathrm{CD} 4{ }^{+} \mathrm{CD} 25^{+}$production $(P<0.001$, Table 5 ; group 1 , class A). However, no significant effect was shown in cultured PBLs (Table 5; group 1, class B).

Table I Changes of IFN- $\gamma$ levels within the control group according to treatment (paired $t$-test)

\begin{tabular}{lll}
\hline Control & IL-2 & IL-2 + IL- 1 2 \\
\hline Mean $(\mathrm{pg} / \mathrm{mL}) \pm S E$ & $4.44 \pm 0.87$ & $127.05 \pm 17.28$ \\
Range & $1.6-9.3$ & $77.0-241.0$ \\
$P$-value & $<0.00 \mathrm{I}$ & \\
\hline
\end{tabular}

Abbreviations: IFN, interferon; IL, interleukin; SE, standard error.
Table 2 IFN- $\gamma$ levels released in the culture media of $\mathrm{HCC}$ samples subjected to treatment with IL-2, IL-4, and IL-I2 (paired t-test)

\begin{tabular}{|c|c|c|c|}
\hline $\begin{array}{l}\text { HCC - mixed } \\
\text { lymphocytes }\end{array}$ & IL-2 & IL-2 + IL-4 & IL-2 + IL-I 2 \\
\hline \multicolumn{4}{|l|}{ (Group I, class A) } \\
\hline Mean $(\mathrm{pg} / \mathrm{mL}) \pm \mathrm{SE}$ & $21.55 \pm 2.64$ & $14.27 \pm 1.90$ & $40.85 \pm 4.64$ \\
\hline Range & II.20-29.00 & $9.00-20.00$ & $25.00-56.00$ \\
\hline \multirow[t]{2}{*}{$P$-value } & \multicolumn{3}{|c|}{ IL-2 + IL-4 versus IL-2; $P<0.05$} \\
\hline & \multicolumn{3}{|c|}{ IL-2 + IL-I 2 versus IL-2; $P<0.00$ I } \\
\hline \multicolumn{4}{|l|}{ blood lymphocytes } \\
\hline \multicolumn{4}{|l|}{ (Group I, class B) } \\
\hline Mean $(\mathrm{pg} / \mathrm{mL}) \pm \mathrm{SE}$ & $49.09 \pm 25.5$ & $66.00 \pm 11.06$ & II $5.43 \pm 28.35$ \\
\hline Range & |3.60-88.00 & $32.0-125.0$ & $55.00-244.00$ \\
\hline$P$-value & \multicolumn{3}{|c|}{ IL-2 + IL-4 versus IL-2; NS } \\
\hline
\end{tabular}

Abbreviations: IFN, interferon; HCC, hepatocellular carcinoma; IL, interleukin; SE, standard error; NS, not significant.

Comparing the initial combined treatment with IL-2 + IL-12 on HCC PBLs, IL-2 + IL-4 revealed a significant elevation in the percentage of $\mathrm{CD} 4{ }^{+} \mathrm{CD} 25^{+} \mathrm{T}$-regs $(P<0.001$; Table 6).

\section{Correlations of IFN- $\gamma$ with IPT and cell count}

In normal control cases, the treatment with IL-2 showed a direct correlation between $\mathrm{CD}^{+}$and IFN- $\gamma\left(\mathrm{CD} 4^{+}\right.$versus IFN- $\gamma ; P=0.042$ ), indicating the role of $\mathrm{CD} 4^{+}$cells in the normal secretion of IFN- $\gamma$. In HCC, IFN- $\gamma$ levels were positively correlated with $\mathrm{CD} 8^{+}$cells during the cotreatment of IL-2 + IL-4 ( $P=0.033)$. Lymphocyte cell count was positively correlated with IFN- $\gamma$ levels during the cotreatment of IL- $2+$ IL-12.

\section{Discussion}

This study offers a new approach for an immunological therapy targeted against liver cancer cells by optimizing conditions that can provide better antitumor immune effects using stimulated T-lymphocytes obtained from the FNA of HCC patients.

Table 3 A comparison of IFN- $\gamma$ levels released in the culture media of HCC peripheral blood lymphocytes according to the two different initial combined treatments (analysis of variance)

\begin{tabular}{llc}
\hline HCC - peripheral & IL-2 + IL-4 & IL-2 + IL- I 2 \\
blood lymphocytes & & \\
\hline Group 2 & & \\
Mean $(\mathrm{Pg} / \mathrm{mL}) \pm$ SE & $80.0 \pm 10.83$ & $130.44 \pm 19.94$ \\
Range & $52.0-138.0$ & $63.4-237.0$ \\
P-value & IL-2 + IL- 12 versus IL-2 + IL-4; $P<0.05$ \\
\hline
\end{tabular}

Abbreviations: IFN, interferon; HCC, hepatocellular carcinoma; IL, interleukin. 
Table 4 Changes in the phenotypic characterization within the control group according to treatment (paired $t$-test)

\begin{tabular}{|c|c|c|c|c|c|c|}
\hline \multirow[t]{2}{*}{ Control } & \multicolumn{2}{|l|}{$\mathrm{CD4}^{+}$} & \multicolumn{2}{|l|}{ CD8 $^{+}$} & \multicolumn{2}{|c|}{$\mathrm{CD4}^{+} \mathrm{CD}^{25^{+}}$} \\
\hline & IL-2 & IL-2 + IL-I 2 & IL-2 & IL-2 + IL-I 2 & IL-2 & IL-2 + IL-I 2 \\
\hline Mean $(\%) \pm S E$ & $49.58 \pm 0.83$ & $57.86 \pm 1.04$ & $22.25+2.73$ & $28.6+1.27$ & $1.33 \pm 0.08$ & $0.86 \pm 0.11$ \\
\hline Range & $46.0-54.2$ & $52.0-62.0$ & II.6-36.3 & $22.0-35.0$ & $1.0-1.8$ & $0.2-1.3$ \\
\hline$P$-value & $<0.001$ & & NS & & $<0.05$ & \\
\hline
\end{tabular}

Abbreviations: $C D$, cluster of differentiation; IL, interleukin; SE, standard error; NS, not significant.

The discovery of T-regs has assisted in making outstanding progress in the research on TILs. T-regs play important roles in the deterioration of the antitumor effects of TILs both in in vivo and in vitro studies. ${ }^{18,19}$ The increased frequency of $\mathrm{CD} 4{ }^{+} \mathrm{CD} 25^{+} \mathrm{T}$-cells in the $\mathrm{CD} 3^{+}$population among HCC patients was thought to be T-regs, ${ }^{19}$ which exhibited potent suppressive activity, as they inhibited the proliferative response of $\mathrm{CD} 4{ }^{+} \mathrm{CD} 25^{-} \mathrm{T}$-cells significantly upon T-cell receptor stimulation by IL-2. ${ }^{20}$

In our assay, the proportion of $\mathrm{CD} 4^{+} \mathrm{CD} 25^{+} \mathrm{T}$-regs in the peripheral blood of HCC patients was significantly elevated in comparison to healthy controls $(P<0.0001)$. This elevation could be due to the secretion of inhibitory factors by the tumors, which may cause an expansion of T-regs, thereby inhibiting the secretion of IFN- $\gamma^{20,21}$ In agreement with our findings, Yang et $\mathrm{al}^{22}$ in 2006 found that T-regs were elevated in HCC liver tissues compared to autologous nontumor regions or normal control tissues. Another previous study ${ }^{23}$ stated that $\mathrm{CD} 4{ }^{+} \mathrm{CD} 25^{+} \mathrm{T}$-cells exert potent immunoregulatory functions and are anergic toward T-cell receptor stimulation in the peripherals, ${ }^{23}$ which was in accordance with the phenomenon of increased migration of T-regs to the marginal regions of the tumor, and with the inhibition of autologous $\mathrm{CD} 8^{+} \mathrm{T}$-cell proliferation.
It has been suggested that the application of IL-12 in combination with IL-2 may be a potent and useful therapeutic option for solid tumors. ${ }^{24} \mathrm{~A}$ study on lung cancer indicated that the synergism between IL-2 and IL-12 increased cytotoxic effects against target cancer cells by regulating cellmediated antitumor immune responses..$^{24}$ IL-12 signaling potentiates the ability of T-cells to become more sensitive to cytokines such as IL-2, which are important for ensuring potent antitumor activity and supporting and maintaining the in vivo proliferation of appropriately primed T-cells. ${ }^{25}$

The overwhelming role in IFN- $\gamma$ secretion played by the subsequent addition of IL-12 to IL-2 was explained by the fact that IFN- $\gamma$ secretion mainly depends on the P38 mitogenactivated protein kinase and stress-activated protein kinase/ Jun N-terminal kinase signaling pathways, which are activated only by the combination of IL-2 and IL-12 in T-cells. These signaling pathways trigger the progressive expression of the IL-2-receptor on cytotoxic cells. ${ }^{26,27}$ Another explanation was that IL-2 and IL-12 synergize together to increase the halflife of IFN- $\gamma$ messenger ribonucleic acid (mRNA), and this is only demonstrated at the level of mRNA stability inside the cytotoxic cells..$^{28}$ Both ILs augmented the IFN- $\gamma$ level and the production of other inflammatory cytokines via nonadherent mononuclear cells in a synergistic or cumulative manner. ${ }^{28}$

Table 5 Percentages of the phenotypic characterization of HCC samples in relation to treatment with different ILs (paired $t$-test)

\begin{tabular}{|c|c|c|c|c|c|c|c|c|c|}
\hline \multirow{2}{*}{$\begin{array}{l}\text { HCC - mixed } \\
\text { lymphocytes }\end{array}$} & \multicolumn{3}{|l|}{$\mathrm{CD4}^{+}$} & \multicolumn{3}{|l|}{$\mathrm{CD8}^{+}$} & \multicolumn{3}{|c|}{$\mathrm{CD}^{+} \mathrm{CD}^{+} 5^{+}$} \\
\hline & IL-2 & IL-2 + IL-4 & IL-2 + IL-I 2 & IL-2 & IL-2 + IL-4 & IL-2 + IL-I 2 & IL-2 & IL-2 + IL-4 & IL-2 + IL-I 2 \\
\hline \multicolumn{10}{|l|}{ (Group I, class A) } \\
\hline Mean $(\%) \pm$ SE & $37.62 \pm 2.79$ & $21.8 \pm 3.7$ & $40.82 \pm 2.37$ & $21.4 \pm 6.8$ & $18.5 \pm 3.2$ & $30.1 \pm 7.5$ & $2.27 \pm 0.34$ & $5.3 \pm 0.5$ & $0.87 \pm 0.19$ \\
\hline Range & $30.70-48.10$ & $12.0-35.9$ & $34.50-49.30$ & $9.8-53.7$ & $8.3-31.2$ & II.6-54.6 & I.20-3.40 & $3.3-6.7$ & $0.30-1.60$ \\
\hline$P$-value & \multicolumn{3}{|c|}{ IL-2 versus IL-2 + IL-12: NS } & \multicolumn{3}{|c|}{ IL-2 versus IL-2 + IL-12: NS } & \multicolumn{3}{|c|}{ IL-2 versus IL- $2+$ IL- I $2<0.05$} \\
\hline \multirow{2}{*}{$\begin{array}{l}\text { HCC - } \\
\text { peripheral blood } \\
\text { lymphocytes }\end{array}$} & \multicolumn{3}{|l|}{$\mathrm{CD4}^{+}$} & \multicolumn{3}{|l|}{ CD8 $^{+}$} & \multicolumn{3}{|c|}{$\mathrm{CD4}^{+} \mathrm{CD25}^{+}$} \\
\hline & IL-2 & IL-2 + IL-4 & $\overline{I L-2}+$ IL-12 & IL-2 & IL-2 + IL-4 & $\overline{I L-2}+$ IL-I2 & IL-2 & IL-2 + IL-4 & IL-2 + IL-I 2 \\
\hline \multicolumn{10}{|l|}{ (Group I, class B) } \\
\hline Mean $(\%) \pm S E$ & $52.13 \pm 3.39$ & $44.7 \pm 2.0$ & $54.23 \pm 3.60$ & $33.1 \pm 3.27$ & $31.76 \pm 2.9$ & $36.2 \pm 2.6$ & $8.76 \pm 1.95$ & $9.4 \pm 1.8$ & $1.77 \pm 0.16$ \\
\hline Range & $34.20-61.0$ & $38.2-51.3$ & $35.50-65.60$ & $24.3-50.8$ & $26.2-48.6$ & $28.7-49.1$ & $1.40-16.50$ & $1.8-16.7$ & $1.20-2.30$ \\
\hline$P$-value & \multicolumn{3}{|c|}{ IL-2 versus IL-2 + IL-I2; NS } & \multicolumn{2}{|c|}{ IL-2 versus IL-2 + IL-I2; NS } & & \multicolumn{3}{|c|}{ IL-2 versus IL-2 + IL-I2; <0.0I } \\
\hline
\end{tabular}

Abbreviations: HCC, hepatocellular carcinoma; CD, cluster of differentiation; IL, interleukin; SE, standard error; NS, not significant. 
Table 6 Percentages of the phenotypic characterization of HCC peripheral blood lymphocytes in relation to treatment with two different initial combined treatments (analysis of variance)

\begin{tabular}{|c|c|c|c|c|c|c|}
\hline \multirow{2}{*}{$\begin{array}{l}\text { HCC - peripheral } \\
\text { blood lymphocytes }\end{array}$} & \multicolumn{2}{|l|}{$\mathrm{CD4}^{+}$} & \multicolumn{2}{|l|}{$\mathrm{CD8}^{+}$} & \multicolumn{2}{|c|}{$\mathrm{CD4}^{+} \mathrm{CD}^{2} 5^{+}$} \\
\hline & IL-2 + IL-4 & IL-2 + IL-I 2 & IL-2 + IL-4 & IL-2 + IL-I 2 & IL-2 + IL-4 & IL-2 + IL-I 2 \\
\hline \multicolumn{7}{|l|}{ (Group 2) } \\
\hline Mean $(\%) \pm S E$ & $44.34 \pm 3.17$ & $42.99 \pm 4.4 \mathrm{I}$ & $29.5 \pm 2.7$ & $33.64 \pm 5.64$ & $10.1 \pm 1.17$ & $2.30 \pm 0.22$ \\
\hline Range & $31.4-55.9$ & $23.4-62.3$ & $23.1-42.7$ & $12.1-48.5$ & $6.3-14.5$ & $1.5-3.1$ \\
\hline$P$-value & NS & & NS & & $<0.001$ & \\
\hline
\end{tabular}

Abbreviations: HCC, hepatocellular carcinoma; CD, cluster of differentiation; IL, interleukin; SE, standard error; NS, not significant.

The study published by Sawayama et $\mathrm{al}^{28}$ in 2003 presented findings that were contrary to our results, where we found that the peripheral T-cells of healthy controls show a higher response to IL-2 + IL-12 for IFN- $\gamma$ secretion than those of patients with $\mathrm{HCC}$; an explanation that supports our results is a study by Ormandy et al in 2005 that explained how $\mathrm{CD} 4{ }^{+} \mathrm{CD} 25^{+}$T-regs were accompanied with very low levels of IFN-g in HCC compared to healthy donors. ${ }^{21}$

Regarding the additive effect of IL-12 to IL-2, our results were supported by several studies. ${ }^{5,29,30}$ These studies on IL-2 and IL-12 gene-transfected HCC models specified that double gene transfection was much more effective than IL-2 gene therapy alone. The findings revealed that the magnitude of response of IFN- $\gamma$ secretion counts on $\mathrm{CD}^{+}{ }^{+} \mathrm{T}$-cells percentages, highlighting the role of $\mathrm{CD} 8^{+}$cells in IL-12-induced tumor rejection.

Regarding the mode of action of IL-12, data from a prior study indicated that the use of IL-12 during in vitro priming significantly altered the phenotype, function, and memory formation of $\mathrm{CD}^{+} \mathrm{T}$-cells. Increased expression of both the high-affinity IL-2R and its downstream transducer, signal transducer and activator of transcription (STAT) 5, clearly potentiated the IL-2 signal. ${ }^{25}$ This explanation supports the enhancement of IFN- $\gamma$ secretion shown in our study.

A previous report stated that IL-12 mediates the selective expansion of inflammatory lymphocyte $\mathrm{CD} 8^{+}$cells, and that it has an inhibitory role on $\mathrm{CD}^{+}$cell propagation. ${ }^{31}$ Comparatively, we disagreed only in that $\mathrm{CD} 4^{+}$cell propagation was found to be non-significantly increased. However, a previous study published by Drescher et $\mathrm{al}^{32}$ in 2005 approved our results concerned with the increase in $\mathrm{CD}^{+}$cell propagation; where they stated that $\mathrm{CD} 4^{+}$TILs are required to be maintained within a certain ratio to $\mathrm{CD} 8^{+} \mathrm{T}$-cells to function optimally. This ratio is the key to appropriate TIL function.

In our study, the addition of IL-12 to IL-2 caused a significant decrease in $\mathrm{CD} 4{ }^{+} \mathrm{CD} 25^{+} \mathrm{T}$-regs and a slight increase in $\mathrm{CD}^{+}{ }^{+} \mathrm{CD} 25^{-} \mathrm{T}$-cells among HCC patients. This could be explained by the previous hypothesis that IL-12 might antagonize the suppressive T-regs through its stimulatory role on $\mathrm{CD} 4^{+}$T-cells. ${ }^{20}$ In healthy controls, the addition of IL-12 to IL-2 showed a significant increase in $\mathrm{CD} 4{ }^{+} \mathrm{CD} 25$ - T-cells and this could be explained by that peripheral blood of healthy controls show lower levels of suppressive $\mathrm{CD} 4^{+} \mathrm{CD} 25^{+} \mathrm{T}$-regs compared to HCC cases. ${ }^{19,22}$

Our study showed that IL-4 antagonizes IL-2 in IFN- $\gamma$ secretion, which is in accordance with a previous report, which stated that the addition of IL-4 to IL-2 in cultured lymphocytes did not result in improving the antitumor effector function in long-term TIL cultures from liver tumors. ${ }^{33}$ In addition, our results agreed with a study published by Castro et $\mathrm{l}^{34}$ in 1999 which stated that the reduced IFN- $\gamma$ level is explained by the inhibitory effect of IL-4 which has been shown to specifically suppress IL-2-induced STAT5 activation in human T-cells and this is a putative mechanism for IL-4 antagonism of $\mathrm{Th}_{1}$ development. Nonetheless, in murine models, researchers reported a contradicting result, as they showed that IL-4 played a synergistic role with IL-2 in the activation of cytotoxic cells to secrete IFN- $\gamma$ in the mixed lymphocyte cultures. ${ }^{35}$ In addition, IL-4 augmented the proliferation of IL-2-activated TIL clones. IL-4 upregulated the IL-2 receptor; consequently, signal transduction was augmented, and the proliferation of TILs was enhanced by IL-4 via the action of the IL-2/IL-2 receptor system. ${ }^{36}$ Further studies are needed to compare the mechanism of action of IL-4 in human and murine models.

On the other hand, several studies have agreed with our results, including a study by Shimizu et $\mathrm{a}^{33}$ that was conducted in 1991, showing that the cytotoxicity of $\mathrm{CD} 8^{+}$cells that originated from liver TILs treated with IL-2 + IL-4 was very low or even undetectable compared to the cytotoxicity noted following treatment with IL-2 alone. Another study has specified that the clonal expansion of $\mathrm{CD}^{+}$and $\mathrm{CD} 8^{+}$ lymphocytes was noted after IL-2 addition, but not IL-2 + IL-4 combined addition. ${ }^{37}$ Moreover, a previous report stated that the presence of IL-4 significantly downregulated IFN- $\gamma$ 
production by IL-2-stimulated cells that were obtained from human healthy volunteers. ${ }^{38}$

\section{Conclusion}

This study has elucidated the idea that the combination of IL-12 and IL-2 has a synergistic effect. Contrary to IL-12, IL-4 has an antagonistic effect in terms of the cytotoxicity of lymphocytes. The mixed lymphocytic population that originated from TILs and PBLs showed a better response whenever they were activated by the subsequent addition of IL-12 to IL-2.

\section{Acknowledgments}

The authors are grateful to the staff of the Cancer Biology Department, NCI, Cairo University, Cairo, Egypt, especially Singer MK, for their valuable support to achieve the present work.

\section{Disclosure}

The authors report no conflicts of interest in this work.

\section{References}

1. Tinkle CL, Haas-Kogan D. Hepatocellular carcinoma: natural history, current management, and emerging tools. Biologics. 2012;6: 207-219.

2. Kobayashi N, Hiraoka N, Yamagami W, et al. FOXP3+ regulatory $T$ cells affect the development and progression of hepatocarcinogenesis. Clin Cancer Res. 2007;13(3):902-911.

3. Shevach EM. CD4+ CD25+ suppressor T cells: more questions than answers. Nat Rev Immunol. 2002;2(6):389-400.

4. Liao W, Lin JX, Leonard WJ. IL-2 family cytokines: new insights into the complex roles of IL-2 as a broad regulator of T helper cell differentiation. Curr Opin Immunol. 2011;23(5):598-604.

5. Kimura Y, Mizuno H, Satake K, Tahara H, Tsukuda M. Effects of combined therapy with interleukin 2 and interleukin 12 gene-transfected tumor vaccine for head and neck carcinoma. Arch Otolaryngol Head Neck Surg. 2003;129(11):1181-1185.

6. Luzina IG, Keegan AD, Heller NM, Rook GA, Shea-Donohue T, Atamas SP. Regulation of inflammation by interleukin-4: a review of “alternatives". J Leukoc Biol. 2012;92(4):753-764.

7. Hamza T, Barnett JB, Li B. Interleukin 12 a key immunoregulatory cytokine in infection applications. Int J Mol Sci. 2010;11(3): 789-806.

8. Li P, Du Q, Cao Z, et al. Interferon- $\gamma$ induces autophagy with growth inhibition and cell death in human hepatocellular carcinoma (HCC) cells through interferon-regulatory factor-1 (IRF-1). Cancer Lett. 2012;314(2):213-222.

9. Schoenborn JR, Wilson CB. Regulation of interferon-gamma during innate and adaptive immune responses. Adv Immunol. 2007;96:41-101.

10. Alshaker HA, Matalka KZ. IFN- $\gamma$, IL-17 and TGF- $\beta$ involvement in shaping the tumor microenvironment: The significance of modulating such cytokines in treating malignant solid tumors. Cancer Cell Int. 2011;11:33.

11. Sprengers D, van der Molen RG, Kusters JG, et al. Flow cytometry of fine-needle-aspiration biopsies: a new method to monitor the intrahepatic immunological environment in chronic viral hepatitis. $J$ Viral Hepat. 2005;12(5):507-512.
12. Vrolijk JM, Tang TJ, Kwekkeboom J, et al. Monitoring intrahepatic CD8+ T cells by fine-needle aspiration cytology in chronic hepatitis C infection. J Viral Hepat. 2004;11(4):342-348.

13. Bøyum A. Isolation of lymphocytes, granulocytes and macrophages. Scand J Immunol. 1976;Suppl 5:9-15.

14. Wing MG, Moreau T, Greenwood J, et al. Mechanism of first-dose cytokine-release syndrome by CAMPATH 1-H: involvement of CD16 (FcgammaRIII) and CD11a/CD18 (LFA-1) on NK cells. J Clin Invest. 1996;98(12):2819-2826.

15. Gajewski TF, Fitch FW. Anti-proliferative effect of IFN-gamma in immune regulation. I. IFN-gamma inhibits the proliferation of Th2 but not Th1 murine helper T lymphocyte clones. J Immunol. 1988; $140: 4245-4252$

16. Papa S; European Working Group on Clinical Cell Analysis. European Working Group on Clinical Cell Analysis (EWGCCA): 6 years on. $J$ Biol Regul Homeost Agents. 2002;16(4):253-256.

17. Nakao M, Yamana H, Imai Y, et al. HLA A2601-restricted CTLs recognize a peptide antigen expressed on squamous cell carcinoma. Cancer Res. 1995;55(19):4248-4252.

18. Maehara Y. Tumor-infiltrating lymphocytes and hepatocellular carcinoma. Int J Clin Oncol. 2010;15(6):543.

19. Shirabe K, Motomura T, Muto J, et al. Tumor-infiltrating lymphocytes and hepatocellular carcinoma: pathology and clinical management. Int J Clin Oncol. 2010;15(6):552-558.

20. Cao M, Cabrera R, Xu Y, et al. Hepatocellular carcinoma cell supernatants increase expansion and function of CD4(+) CD25(+) regulatory T cells. Lab Invest. 2007;87(6):582-590.

21. Ormandy LA, Hillemann T, Wedemeyer H, Manns MP, Greten TF, Korangy $\mathrm{F}$. Increased populations of regulatory $\mathrm{T}$ cells in peripheral blood of patients with hepatocellular carcinoma. Cancer Res. 2005;65(6):2457-2464.

22. Yang XH, Yamagiwa S, Ichida T, et al. Increase of CD4+ CD25+ regulatory T-cells in the liver of patients with hepatocellular carcinoma. J Hepatol. 2006;45(2):254-262.

23. Wolf AM, Wolf D, Steurer M, Gastl G, Gunsilius E, GrubeckLoebenstein B. Increase of regulatory $\mathrm{T}$ cells in the peripheral blood of cancer patients. Clin Cancer Res. 2003;9(2):606-612.

24. Hiraki A, Kiura K, Yamane H, et al. Interleukin-12 augments cytolytic activity of peripheral blood mononuclear cells against autologous lung cancer cells in combination with IL-2. Lung Cancer. 2002;35(3): 329-333.

25. Lisiero DN, Soto H, Liau LM, Prins RM. Enhanced sensitivity to IL-2 signaling regulates the clinical responsiveness of IL-12-primed CD8(+) T cells in a melanoma model. J Immunol. 2011;186(9):5068-5077.

26. Wang KS, Frank DA, Ritz J. Interleukin-2 enhances the response of natural killer cells to interleukin-12 through up-regulation of the interleukin-12 receptor and STAT4. Blood. 2000;95(10): 3183-3190.

27. Pintaric M, Gerner W, Saalmüller A. Synergistic effects of IL-2, IL-12 and IL-18 on cytolytic activity, perforin expression and IFN-gamma production of porcine natural killer cells. Vet Immunol Immunopathol. 2008;121(1-2):68-82.

28. Sawayama T, Sakaguchi K, Senoh T, et al. Effects of pulsing procedure of interleukin-12 in combination with interleukin-2 on the activation of peripheral blood lymphocytes derived from patients with hepatocellular carcinoma. Acta Med Okayama. 2003;57(6):285-292.

29. You TG, Wang HS, Yang JH, Qian QJ, Fan RF, Wu MC. Transfection of IL-2 and/or IL-12 genes into spleen in treatment of rat liver cancer. World J Gastroenterol. 2004;10(15):2190-2194.

30. Komita H, Homma S, Saotome H, Zeniya M, Ohno T, Toda G. Interferon-gamma produced by interleukin-12-activated tumor infiltrating CD8+ T cells directly induces apoptosis of mouse hepatocellular carcinoma. J Hepatol. 2006;45(5):662-672.

31. Kelly AM, Golden-Mason L, McEntee G, et al. Interleukin 12 (IL$12)$ is increased in tumour bearing human liver and expands CD8(+) and CD56(+) T cells in vitro but not in vivo. Cytokine. 2004;25(6): 273-282. 
32. Drescher KM, Lynch HT. Tumor infiltrating lymphocytes (TILs): lessons learned in 30 years of study. Clin Appl Immunol Rev. 2005;5(3):149-166.

33. Shimizu Y, Iwatsuki S, Herberman RB, Whiteside TL. Effects of cytokines on in vitro growth of tumor-infiltrating lymphocytes obtained from human primary and metastatic liver tumors. Cancer Immunol Immunother. 1991;32(5):280-288.

34. Castro A, Sengupta TK, Ruiz DC, Yang E, Ivashkiv LB. IL-4 selectively inhibits IL-2-triggered Stat5 activation, but not proliferation, in human T cells. J Immunol. 1999;162(3):1261-1269.

35. Bream JH, Curiel RE, Yu CR, et al. IL-4 synergistically enhances both IL-2- and IL-12-induced IFN-gamma expression in murine NK cells. Blood. 2003;102(1):207-214.
36. Tsunoda $\mathrm{T}$, Tanimura $\mathrm{H}$, Yamaue $\mathrm{H}$, et al. Clonal and functional analysis for the augmentation of tumour-infiltrating lymphocytes by interleukin 4. Br J Cancer. 1996;74(7):1085-1089.

37. Peng BG, Liang LJ, He Q, Huang JF, Lu MD. Expansion and activation of natural killer cells from PBMC for immunotherapy of hepatocellular carcinoma. World J Gastroenterol. 2004;10(14):2119-2123.

38. Goleva E, Li LB, Leung DY. IFN-gamma reverses IL-2 and IL-4-mediated T-cell steroid resistance. Am J Respir Cell Mol Biol. 2009;40(2):223-230.

\section{Publish your work in this journal}

The Journal of Hepatocellular Carcinoma is an international, peerreviewed, open access journal that offers a platform for the dissemination and study of clinical, translational and basic research findings in this rapidly developing field. Development in areas including, but not limited to, epidemiology, vaccination, hepatitis therapy, pathology and molecular tumor classification and prognostication are all considered for publication. The manuscript management system is completely online and includes a very quick and fair peer-review system, which is all easy to use. Visit http://www.dovepress.com/testimonials.php to read real quotes from published authors.

Submit your manuscript here: http://www.dovepress.com/journal-of-hepatocellular-carcinoma-journal 